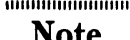

Hote

\section{A Survey of Cross-resistance between Kasugamycin and Other Protein Biosynthesis Inhibitors in Pyricularia oryzae}

\section{Masako KATAGIRI and Yasuhiko UesugI}

\author{
National Institute of Agro-Environmental \\ Sciences, Yatabe-machi, Tsukuba, \\ Ibaraki 305, Japan
}

(Received October 18, 1985)

Development of resistance to kasugamycin in rice blast fungus, Pyricularia oryzae, in the field has already been reported by Miura et al. ${ }^{1)}$ While the mechanism of resistance to kasugamycin has not been elucidated in the resistant strains emerged in the field, the mechanism of a laboratory-derived resistant mutant was already reported by Misato and Ko. ${ }^{2)}$ They suggested a loss of affinity of the antibiotic to the fungal ribosomes, which are the site of action of the antibiotic, as the resistance mechanism.

Blasticidin $\mathrm{S}$ is another antibiotic effective to rice blast. The antibiotic inhibits protein biosynthesis in the fungus. ${ }^{3)}$ Cross-resistance between kasugamycin and blasticidin $\mathrm{S}$ in $P$. oryzae has been investigated and both presence ${ }^{4,5)}$ and absence ${ }^{1,6)}$ of the cross-resistance have been observed. Since the genetic analysis of fungicide resistance is very difficult in $P$. oryzae isolated from rice plants, Taga and his co-workers ${ }^{7)}$ conducted genetic analysis of the resistance in Pyricularia sp. isolated from finger millet which could be crossed, and its genes were analyzed for the resistance much more easily than those of $P$. oryzae. As a result of analyses of various resistant mutants obtained in the laboratory, they identified three loci for the resistance to kasugamycin, among which one locus was responsible for crossresistance to blasticidin S. On the contrary, the resistance to the antibiotics in $P$. oryzae occurring in the field has never been studied from genetic and biochemical standpoints.

In the present investigation, a survey of the cross-resistance of $P$. oryzae between kasugamycin and other inhibitors of protein biosynthesis was conducted to get information on similarities in resistance mechanism among the test strains.

Test strains were six field-isolates sensitive to kasugamycin, five field-isolates resistant to kasugamycin, and two resistant mutants selected under laboratory condition from a large number of conidia. The two resistant mutants were derived from two of the above six sensitive fieldisolates.

Inhibitors tested in comparison with kasugamycin were two fungicides, cycloheximide and blasticidin S, five bactericides, chloramphenicol, erythromycin, puromycin, streptomycin and tetracycline, and nine herbicides stated later. The mechanism of action of the test fungicides and bactericides is said to be inhibition of fungal or bacterial protein biosynthesis. The primary mechanism of herbicidal action of the test herbicides is, however, not necessarily inhibition of protein biosynthesis, but they are reported to inhibit the incorporation of animo acid(s) into protein fraction in higher plants and other organisms. ${ }^{8)}$

Discs of $4 \mathrm{~mm}$ diameter were cut by a cork borer from mycelial mats of test strains grown on plates of potato sucrose agar (PSA) medium, put on plates of PSA containing test chemicals and cultured for 7 days at $27^{\circ} \mathrm{C}$. Inhibition of radial growth of the mycelial mats by the test chemicals was calculated in comparison with the radial growth on untreated PSA plates. The sensitivity to the test chemicals was represented by the values thus obtained.

Examples of the test results are shown in correlograms indicating the correlation between sensitivity to test chemicals and sensitivity to kasugamycin (Fig. 1). All the five bactericides tested showed no or little fungicidal activity to all the test strains at $100 \mu \mathrm{g} / \mathrm{ml}$, indicating no correlation in cross-resistance between kasugamycin and the bactericides. In contrast, most of herbicides tested are more or less fungicidal. Among them, barban, propanil and chlorpropham clearly showed fungicidal activity at $32 \mu \mathrm{g} / \mathrm{ml}$, but there was no significant difference in sensitivity to the herbicides among all the fieldisolates and mutants. The four herbicides, alachlor, benthiocarb, butachlor and molinate, showed fungicidal activity at $100 \mu \mathrm{g} / \mathrm{ml}$. Asulam and EPTC were almost non-fungicidal. No significant difference in sensitivity was observed among the strains tested either. 
(a)

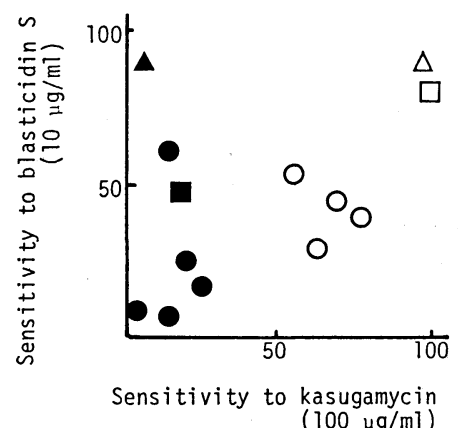

(b)

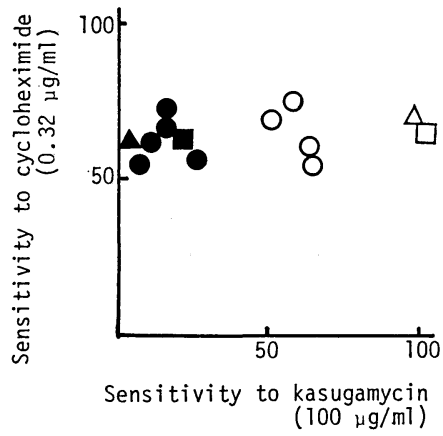

Fig. 1 Correlation of sensitivity to kasugamycin with sensitivity to blasticidin S (a) and cycloheximide (b) among various strains of Pyricularia oryzae.

Sensitivity is expressed by percent inhibition of radial growth of mycelial mat on agar plates by the fungicides. Test fungi are kasugamycin-sensitive fieldisolates $(\bigcirc, \Delta, \square)$, resistant field-isolates $(\bullet)$, resistant mutants $(\boldsymbol{\Delta}, \boldsymbol{\square})$ derived from two of the above field-isolates $(\Delta, \square)$ under laboratory condition.

Both antibiotics, cycloheximide and blasticidin $\mathrm{S}$, were fungicidal. The sensitivity of the fieldisolates and mutants to blasticidin $\mathrm{S}$ varied (Fig. $1 \mathrm{a})$, while their sensitivity to cycloheximide was almost same (Fig. $1 \mathrm{~b}$ ). Most of field-isolates seemed to show cross-resistance between kasugamycin and blasticidin S. But at least one fieldisolate and one laboratory-derived mutant resistant to kasugamycin were not necessarily crossresistant to blasticidin $\mathrm{S}$. The result suggests the existence of more than one kind of kasugamycin-resistant strains; one is cross-resistant to blasticidin $\mathrm{S}$ and the other is not. This result may reflect the existence of two or more genes for kasugamycin resistance.

No cross-resistance between kasugamycin and each of fifteen chemicals other than blasticidin $\mathrm{S}$ was observed in the present investigation.

Authors are indebted to manufacturers for the gift of pesticides tested in the present study.

\section{REFERENCES}

1) H. Miura, H. Ito \& S. Takahashi: Ann. Phytopathol. Soc. Jpn. 41, 415 (1975)

2) T. Misato \& K. Ko: "Pesticides,", Environmental Quality and Safety Suppl. 3, ed. by F. Coulston \& F. Korte, Georg Thieme Publ., Stuttgart, pp. 437-440, 1975

3) T. Misato, Y. Okimoto, I. Ishii, M. Asakawa \& K. Fukunaga: Ann. Phytopathol. Soc. Jpn. 26, 25 (1961)

4) B. K. Hwang \& H. S. Chung: Phytopathology
67, 421 (1977)

5) H. Sakurai: J. Antibiot. 29, 1341 (1976)

6) I. Ito \& T. Yamaguchi: Ann. Phytopathol. Soc. Jpn. 43, 301 (1977)

7) M. Taga, H. Nakagawa, M. Tsuda \& A. Ueyama: Pytopathology 69, 463 (1979)

8) K. Kobayashi \& K. Ishizuka: "Pesticide Design-strategy and Tactics," ed. by I. Yamamoto \& J. Fukami, Soft Science Inc., Tokyo, pp. $415-426,1979$

要 約

\section{イネいもち病菌におけるカスガマイシンと各種タンパ ク合成阻害剂との交差耐性の検索}

片桐政子，上杉康彦

タンパク合成阻害剤であるカスガマイシンに感受性を異にす る各種イネいもち病菌菌株を供試し, 選択性を異にする各種タ ソパク合成阻害剂の抗菌力を測定して，カスガマイシンとの交 差耐性を検討した. 5 種の抗細菌性抗生物質および除草郕】 シュラム, EPTCは $100 \mu \mathrm{g} / \mathrm{ml}$ ですべての菌株に対して殺菌活 性を示さなかった。除草郕 barban, propanil, chlorpropham は $32 \mu \mathrm{g} / \mathrm{ml}$, 抗かび性抗生物質 cycloheximide は $0.32 \mu \mathrm{g} / \mathrm{ml}$ で すべての菌株に対して殺菌活性を示したが，カスガマイシンと の交差耐性は見られなかった. カスガマイシンとブラストサイ ジン S との間に交差耐性を示す菌株が多かったが，前者のみに 耐性を示す室内变異菌株および固場分離菌株もあり，カスガマ イシン耐性を支配する遺伝因子が複数個存在することが示唆さ れた。 